\title{
worldview
}

a JOURNAL OF RELIEION AND INTERNATIONAL AFFAIRS

\section{THE DUTY TO NEGOTIATE}

The history of Western-Soviet relations is a history of frustration, and the foreign ministers' conference in Geneva has added one more footwote to it. The United States did not, of course, bring to the meeting much more than a weary expectation of inevitable deadlock, and neither, probably, did the Soviet Union. But the Western powers expected the Communists to pay at least me token price for a summit conference, and oven this was not forthcoming. The ministers thus recessed with their last condition, to all appearances, worse than their first.

This dashing of even our minimal hopes has given new strength to those who see the present world struggle as a clear-cut battle between Good and Evil, in which no accommodation, no compromise will ever be possible. These people denounce any attempt at negotiations with the Communist powers as a moral betrayal, and the "militant" anti-Communist press in this country, which seems to take positive delight in the breakdown of diplomacy, is now hailing the stalemate at Geneva as "proof" that further attempts at Western-Soviet conciliation are folly.

-

The complexities of the Berlin problem-the reasons why no real "progress" toward its solution could be hoped for among the foreign ministers -have been fully, and diversely, explored by most of the nation's foreign policy analysts. What concerns us here is the resurgence in this country of the spirit of "no negotiations at all." This spirit in the long run could prove a greater danger for the United States and for the world than any number of Soviet ultimatums.

Both West and East are playing the most dangerous game in history-the twentieth century game of nuclear roulette. The only chance of averting its consequences lies in the continuing respites of negotiation and contacts, no matter bow abortive these may seem.

The moral obligation to negotiate was recently set forth by Alfredo Cardinal Ottaviani, ProPrefect of the Sacred Congregation of the Holy Office in the Vatican, during a visit to the United States. The Cardinal's words are especially significant since he is widely identified with the "right-wing" or "conservative" faction in the Roman Curia.

"Would it do any good for the free nations of the world to isolate the Soviet Union?" Cardinal Ottaviani was asked in a public interview. His reply was unequivocal: "Absolutely not. Should the world isolate the Soviet regime, then it would consider itself under siege. The net effect of such action would be to revive its revolutionary Communist fervor."

The West, the Cardinal insisted, "must continue to negotiate," and it must "leave the door open for the Soviets to enter the polity of nations." And though the Western nations "must guard against any compromise or concession that would encourage Soviet intransigence," the most important task they face "is to keep contact-not to close the Soviet Union off."

The Cardinal's statement is a strong rebuke to those who too readily seize upon fresh evidence of Soviet inflexibility as an excuse for ending all attempts at accommodation, or who, callous to the consequences for the human race, urge some kind of "crusade" against the Soviet Union. Because the developments in modern technology have left us with one overriding moral obligation, an obligation we owe to the past and to the future as well as to ourselves-the obligation to avert the catastrophe of nuclear war.

This obligation means that we must continue to negotiate and to explore, even when negotiation seems fruitless and exploration grows wearisome beyond bearing. It means that we must maintain and increase personal contacts, on the highest level possible, between the Soviet Union and the West, even when we find such contacts personally objectionable. The issues here involved far transcend matters of personal objection. 